\title{
Design and Simulation of Dual Input DC/DC Converter
}

\author{
Sushmita N. Shetty ${ }^{1}$, Md. Abdul Raheman ${ }^{2}$ \\ PG Scholar, Mechanical Engineering, NMAM Institute of Technology, Nitte, India ${ }^{1}$ \\ Assistant Professor, Electrical \& Electronics Engineering, NMAM Institute of Technology, Nitte, India ${ }^{2}$
}

\begin{abstract}
In this paper a Dual Input DC/DC Converter (DIC) is proposed for Hybridization of renewable and storage energy sources. The converter provides a regulated voltage at the load. The two input sources to the converter may include Photo Voltaic (PV) cell, Fuel cell, Wind source etc. Converter may beoperated in Buck, Boost or Buck-Boost modes. Based on the operating conditions power is delivered to load from thetwo sources either simultaneously or individually. The complete DIC hassmaller size hence overall cost is reduced due to the less number of components. Using MATLAB/Simulink software proposed converter is simulated and performance of the converter is analysed.
\end{abstract}

Keywords: Dual input DC/DC converter, PV cell, Battery, MATLAB/Simulink.

\section{INTRODUCTION}

Hybrid energy system (HES) is a growing technology that is capable of meeting future energy needs. HES are sustainable and reliable sources of energy compared to conventional sources. In this system, non-conventional sources and renewable energy sources are interfaced to power the load. HES provides reliable operation, high durability, it is a clean form of energy and gives efficient operation.It also has better power handling capability during steady-state operation and better dynamic response during transients.In HES, an interfacing circuit is used to interface different energy sources of different V-I characteristics and power ratings to meet the load demand [9].

Multiple-input DC/DC converters (MICs) are widely used in interfacing different energy sources. Energy sources like solar panel, wind energy source, fuel cell, ultra capacitor etc. with different V-I characteristic are interfaced using single-input DC/DC converter then their outputs are combined to supply load by connecting single converters in series or parallel [3]. However, such configurations are costlier, bulky and complex in design and also reduce the overall efficiency as well as reliability of the system. Hence, multiple single-input DC/DC converters are used in place of single multiple-input DC/DC converter. MICs are simple and compact in design and less costly. In addition, they provide efficient DCpower distribution at regulated output voltage which increases the reliability of the converter.

Several isolated and non-isolated topologies of MIC have been proposed. The isolated topologies are based on magnetically connected circuit (MCC) and non-isolated topologies are based on electrically connected circuit (ECC). In MCC, for energy transformation from sources to load flux addition along with time domain multiplexing technique is commonly used. The presence of transformer along with additional peripheral circuitry makes MCC complex, bulky, costly and increases dependency on circuit parameters. ECC has modular structure, which reduces cost and absence of transformer makes it attractive and minimizes the issue associated with MCC [1].

The electrically connected MIC topologies combine various input energy sources either in parallel or in series. The major drawback of parallel connected source topologies is that, input source voltages should be asymmetric and only one input source can supply power to the load at a time to avoid power coupling effect. In order to supply power simultaneously, input sources are connected in series.

However, such configurations are costly, bulky and relatively complex in design and reduce overall efficiency as well as reliability of system. Therefore, multiple singlesource DC/DC converters have been successfully replaced with a dual input converter (DIC) or multiple input converters (MIC). It offers simple and more compact design and reduces the cost and complexity of the system. In addition efficient DC power distribution and higher degree of flexibility can be achieved [5].

The dual input DC/DC converter has the ability to transfer power from different sources individually or simultaneously either in series or parallel combination of sources. It has capability of producing regulated dc bus voltage, which is subsequently interfaced with electric load through front end converter with improved dynamic response. The designed converter is proficient in energy diversification from different sources but it also offers power flow control among both the source and load. In 
addition, proposed topology can be operated in buck, buck-boost or boost modes. It offers bidirectional flow of power, compact design and flexibility in control as well as selection of input source voltage magnitude (i.e. symmetric or asymmetric).

\section{CONVERTER TOPOLOGY AND WORKING}

\section{A. Converter Topology}

Basic structure of Dual input DC/DC buck-boost converter is as shown in Fig. 1. In this topology, switches $T_{1}$ and $T_{2}$ are bidirectional conduction and bidirectional blocking (BCBB) in nature. The diodes D1 and D2 offers freewheeling of load current. This structure consists of switches that are connected with two input sources which are in turn connected to load through basic converter circuit, which consists of two switches $T_{3}$ and $T_{4}$ along with inductor and capacitor for buck-boost operation.

Combination of switches $\mathrm{T}_{1}, \mathrm{~T}_{2}$ chooses the mode of operation of this buck-boost converter. Buck-boost capability is given by switch $\mathrm{T}_{3}$, while bidirectional operation to the DC/DC converter is provided by switch $\mathrm{T}_{4}$. It has two input dc voltage sources namely $\mathrm{E}_{1}$ and $\mathrm{E}_{2}$, where Eo is the output voltage and Io is the load curren

This converter has four modes of operation.

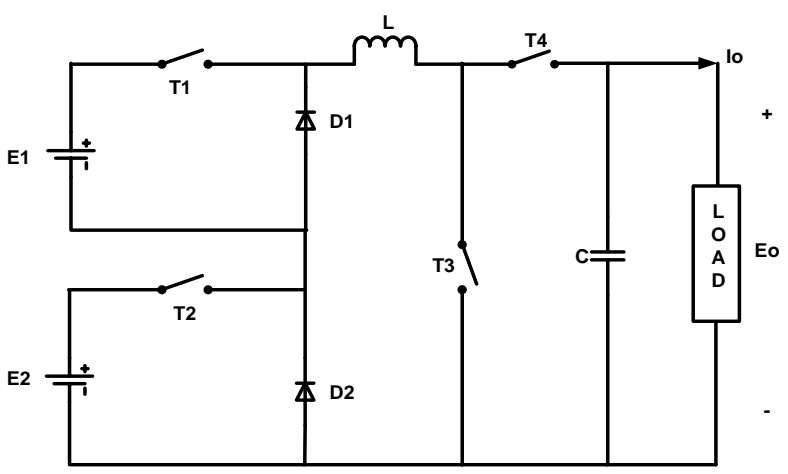

Fig. 1: Basic structure of Dual input DC/DC converter

B. Working

There are four operating states; working of each state is as stated in TABLE I below;

TABLE I: WORKING STATES

\begin{tabular}{|c|c|c|c|c|}
\hline $\begin{array}{c}\text { Working } \\
\text { State }\end{array}$ & $\begin{array}{c}\text { Source } \\
\text { supplying }\end{array}$ & $\begin{array}{c}\text { Active } \\
\text { switch }\end{array}$ & $\begin{array}{c}\text { Inductor } \\
\text { voltage }\end{array}$ & $\begin{array}{c}\text { Inducto } \\
\text { r status }\end{array}$ \\
\hline State 1 & $\mathrm{E}_{1}$ & $\begin{array}{c}\mathrm{T}_{1} \text { and } \\
\mathrm{T}_{3}\end{array}$ & $\mathrm{E}_{1}$ & $\begin{array}{c}\text { Chargi } \\
\text { ng }\end{array}$ \\
\hline State 2 & $\mathrm{E}_{2}$ & $\begin{array}{c}\mathrm{T}_{2} \text { and } \\
\mathrm{T}_{3}\end{array}$ & $\mathrm{E}_{2}$ & $\begin{array}{c}\text { Chargi } \\
\text { ng }\end{array}$ \\
\hline State 3 & $\mathrm{E}_{1}$ and $\mathrm{E}_{2}$ & $\begin{array}{c}\mathrm{T}_{1}, \mathrm{~T}_{2} \\
\text { and } \mathrm{T}_{3}\end{array}$ & $\mathrm{E}_{1}+\mathrm{E}_{2}$ & $\begin{array}{c}\text { Chargi } \\
\text { ng }\end{array}$ \\
\hline State 4 & None & $\mathrm{T}_{4}$ & $\mathrm{E}_{\mathrm{o}}$ & $\begin{array}{c}\text { Dischar } \\
\text { ging }\end{array}$ \\
\hline
\end{tabular}

III.

\section{STEADY STATE ANALYSIS}

Depending on the switching strategy of switches various operation states are obtained. Based on the power utilization of sources, switching scheme is selected. There are three ways for generating gate pulsenamely; a) Rising edge synchronization, b) Falling edge synchronization and c) Intermediate synchronization of gate pulses.

The different operating time over single switching cycle in terms of duty cycle can be defined as;

$$
\begin{aligned}
\mathrm{t}_{1} & =\left(\mathrm{d}_{1}-\mathrm{d}_{12}\right) \text { Ts } \\
\mathrm{t}_{2} & =\mathrm{d}_{12} \mathrm{Ts} \\
\mathrm{t}_{3} & =\left(\mathrm{d}_{2}-\mathrm{d}_{12}\right) \text { Ts } \\
\mathrm{t}_{4} & =\left(1-\mathrm{d}_{1}-\mathrm{d}_{2}+\mathrm{d}_{12}\right) \text { Ts }(4)
\end{aligned}
$$

Where, $d_{1}$ and $d_{2}$ are the duty ratio of switches $T_{1}$ and $T_{2}$ respectively.

Intermediate synchronization switching sequence of fixed frequency is used for generating gate pulse.For the analysis it is assumed that switching loss is zero and inductor and capacitor drops are negligible. Voltage across the load is maintained constant due to the large capacitor present. From the Fig.2, for the time t1, E1 supplies power to load, for $\mathrm{t} 2$ seconds sources are connected in series, for time $\mathrm{t} 3$, E2 supplies, for the period $\mathrm{t} 4$ both the sources are inactive.

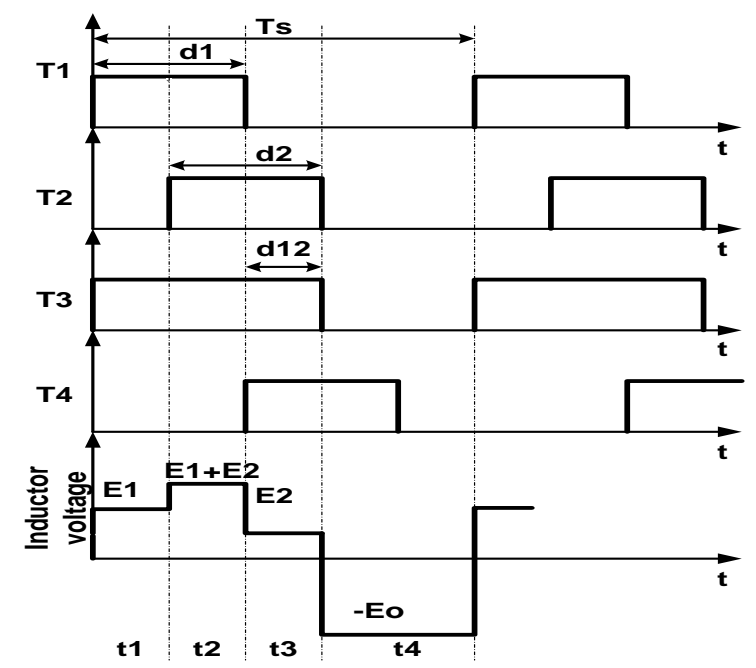

Fig. 2: Analytic analysis of inductor voltage waveform

Therefore inductor voltage, when switch $\mathrm{T} 1$ is conducting for time duration $\mathrm{t}_{1}$

$$
\mathrm{e}_{\mathrm{L}}=\mathrm{E}_{1} * \mathrm{t}_{1}
$$

Inductor voltage when switch $\mathrm{Ts}$ is conducting for time duration $\mathrm{t} 2$

$$
\mathrm{e}_{\mathrm{L}}=\left(\mathrm{E}_{1}+\mathrm{E}_{2}\right) * \mathrm{t}_{2} \quad(6)
$$

When switch T2 is conducting for time duration $t_{3}$

$$
\mathrm{e}_{\mathrm{L}}=\mathrm{E}_{2} * \mathrm{t}_{3} \quad \text { (7) }
$$

And, When all the switch are OFF for time $\mathrm{T}=\mathrm{t}_{4}$

$$
e_{L}=\left(-E_{0}\right) T_{\text {off }} \quad(8)
$$




\author{
National Conference on Advances in Electrical Engineering \\ NMAM Institute of Technology, Nitte \\ Vol. 5, Special Issue 2, April 2017
}

In steady state operation, by volt-second balance equation, The photocurrent mainly depends on the solar insolation the average inductor voltage should be zero.Therefore,

Average inductor voltage $=\int_{0}^{T s} e_{L}=0$ (9)

Here, $\mathrm{e}_{\mathrm{L}}=$ Voltage across inductor and Ts is the switching period of one cycle;

$$
\mathrm{T}_{\mathrm{s}}=\left(\mathrm{T}_{\mathrm{on}}+\mathrm{T}_{\text {off }}\right)
$$

Therefore,

$$
\int_{0}^{\mathrm{T}_{\mathrm{s}}} \mathrm{e}_{\mathrm{L}}=\left(\mathrm{E}_{1} * \mathrm{t}_{1)}+\left(\left(\mathrm{E}_{1}+\mathrm{E}_{2}\right) * \mathrm{t}_{2}\right)+\left(\mathrm{E}_{2} * \mathrm{t}_{3}\right)+\left(-\mathrm{E}_{0)} \mathrm{T}_{\text {off }}=0\right.\right.
$$

Simplifying the equation (11) we get input-output voltage relationship as,

$$
E_{0}=\frac{E_{1} d_{1}+E_{2} d_{2}}{\left(1-d_{1}-d_{2}+d_{12}\right)}
$$

Where $d_{1}=\frac{t_{1}+t_{2}}{T_{s}}, d_{2}=\frac{t_{2}+t_{3}}{T_{s}}, d_{12}=\frac{t_{2}}{T_{s}}$.

Inductor current ripple $(\Delta \mathrm{i})$ and capacitor ripple voltage $(\Delta v)$ can be used to determine the value of inductance and capacitance used in the system, respectively.

$$
\begin{gathered}
\Delta \mathrm{i}=\frac{\mathrm{E}_{\mathrm{o}}\left\{1-\mathrm{d}_{1}-\mathrm{d}_{2}+\mathrm{d}_{12}\right\}}{\mathrm{L} * \mathrm{f}_{\mathrm{S}}}(13) \\
\Delta \mathrm{v}=\frac{\mathrm{E}_{\mathrm{o}}\left(\mathrm{d}_{1}+\mathrm{d}_{2}-\mathrm{d}_{12}\right)}{\mathrm{R} * \mathrm{C} * \mathrm{f}_{\mathrm{S}}}(14)
\end{gathered}
$$

\section{IV.INPUT SOURCES}

Dual Input Converter is powered using solar energy source and battery.

\section{PV Cell}

A solar cell is basically a $\mathrm{p}-\mathrm{n}$ semiconductor junction. When light falls on its surface a dc current is generated. With the change in solar irradiance the produced current varies.

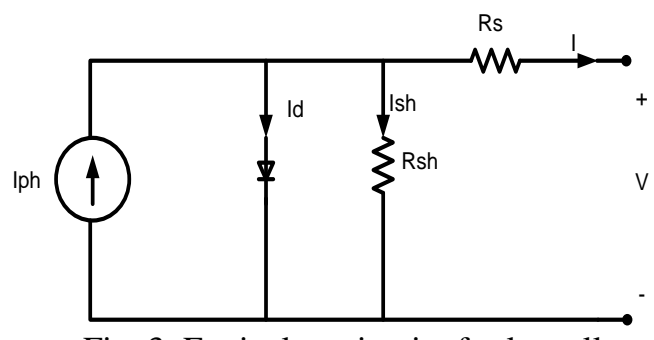

Fig. 3: Equivalent circuit of solar cell

The current-voltage characteristic equation of a solar cell is given as

Where,

$$
I=I_{p h}-I_{0}\left[e^{\frac{q(V+I * R s)}{n * k * T}}-1\right]-\frac{V+I * R s}{R s h}(15)
$$

$I_{p h}$ is the Light-generated current or photocurrent, $I_{0}$ is diode reverse saturation current $(\mathrm{A}), \mathrm{q}$ is the electron charge $\left(1.602 \times 10^{-19} \mathrm{C}\right), \mathrm{K}$ is the Boltzmann's constant $\left(1.381 \times 10^{-23} \mathrm{~J} / \mathrm{K}\right), \mathrm{T}$ is the junction temperature in Kelvin $(\mathrm{K}), \mathrm{R}_{\mathrm{s}}$ is the series resistance, $\mathrm{R}_{\mathrm{p}}$ is the parallel resistance. and cell's working temperature, which is described as

$$
\mathrm{Iph}=[\text { Iph,ref }+\mathrm{KI}(\mathrm{T}-\mathrm{Tn})] \boldsymbol{\alpha}(16)
$$

Where,

$\mathrm{KI}$ is the cell's short circuit temperature coefficient, Tn is Cell's reference temperature, $\boldsymbol{\alpha}$ is the solar insolation in $\mathrm{kw} / \mathrm{m}^{2}$.

The parameters of solar array (SLP010 at $25^{\circ} \mathrm{C}$ and $1000 \mathrm{~W} / \mathrm{m}^{2}$ ) were chosen for modelling and simulation using MATLAB/Simulink are given in TABLE II.

TABLE II: PARAMETERS OF SOLAR PANEL

\begin{tabular}{|l|c|}
\hline At temperature & $25^{\circ} \mathrm{C}$ \\
\hline Open circuit voltage, $\mathrm{V}_{\mathrm{OC}}$ & $20.6 \mathrm{~V}$ \\
\hline Short circuit current, $\mathrm{I}_{\mathrm{SC}}$ & $0.69 \mathrm{~A}$ \\
\hline Voltage at maximum power, $\mathrm{V}_{\mathrm{mp}}$ & $17.3 \mathrm{~V}$ \\
\hline Current at maximum power, $\mathrm{I}_{\mathrm{mp}}$ & $0.58 \mathrm{~A}$ \\
\hline Maximum power, $\mathrm{P}_{\mathrm{m}}$ & $10 \mathrm{~W}$ \\
\hline No. of cells in parallel, $\mathrm{N}_{\mathrm{p}}$ & 1 \\
\hline No. of cells in series, $\mathrm{N}_{\mathrm{s}}$ & 36 \\
\hline
\end{tabular}

\section{Battery}

Battery consists of one or more electro-chemical cells. It is provided with external connections for powering external devices. Cathode is positive terminal and anode is negative terminal. The negative terminal will provide power to external devices.

\section{SIMULATION RESULTS}

Dual Input DC/DC Converter is simulated using MATLAB/Simulink to verify the theoretical results. It has 4 modes of operation.

\section{TABLE III: SIMULATION PARAMETERS}

\begin{tabular}{|l|l|}
\hline Parameter & Value \\
\hline $\mathrm{E}_{1}$ & $12 \mathrm{~V}$ \\
\hline $\mathrm{E}_{2}$ & $6 \mathrm{~V}$ \\
\hline $\mathrm{R}$ & $10 \Omega$ \\
\hline $\mathrm{C}$ & $240 \boldsymbol{\mu F}$ \\
\hline $\mathrm{L}$ & $634.36 \mu \mathrm{H}$ \\
\hline Current ripple & $5 \%$ \\
\hline $\mathrm{f}_{\mathrm{s}}($ switching frequency) & $50 \mathrm{kHz}$ \\
\hline Duty ratio (series) $\mathrm{d}_{1}, \mathrm{~d}_{2}, \mathrm{~d}_{12}$ & $0.4,0.4,0.2$, \\
\hline
\end{tabular}

E. Series mode of operation

In this mode of operation switches $\mathrm{T}_{1}$ and $\mathrm{T}_{2}$ are operated in an intermediate synchronizing manner. Inductor voltage changes from $E_{1}, E_{1}+E_{2}$ and $E_{2}$ consequently due to the series combination of sources. Fig. 6 shows linear rise in inductor current in three steps of different slope and inductor voltage during the series operation. Therefore, it can be concluded from inductor voltage and current 
waveform that by controlling the duty cycle of each switch of corresponding source controlled charging and discharging of inductor can be achieved. Hence regulated output voltage can be obtained by controlled power diversification from each source. The loadcurrent and load voltage waveforms for series combination of sources are as shown in Fig. 7.
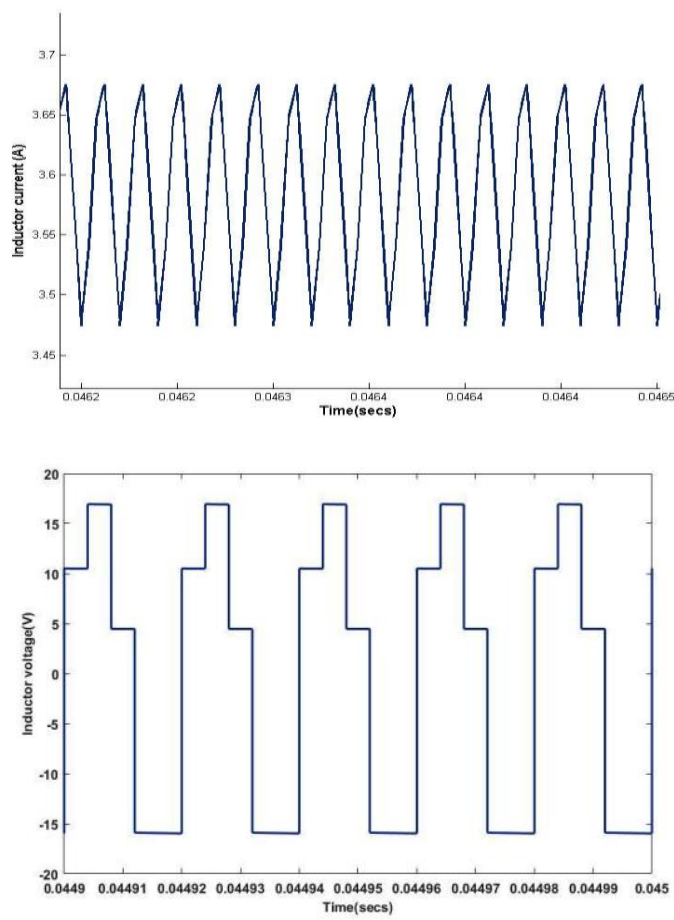

Fig. 6: Inductor current and voltage waveform
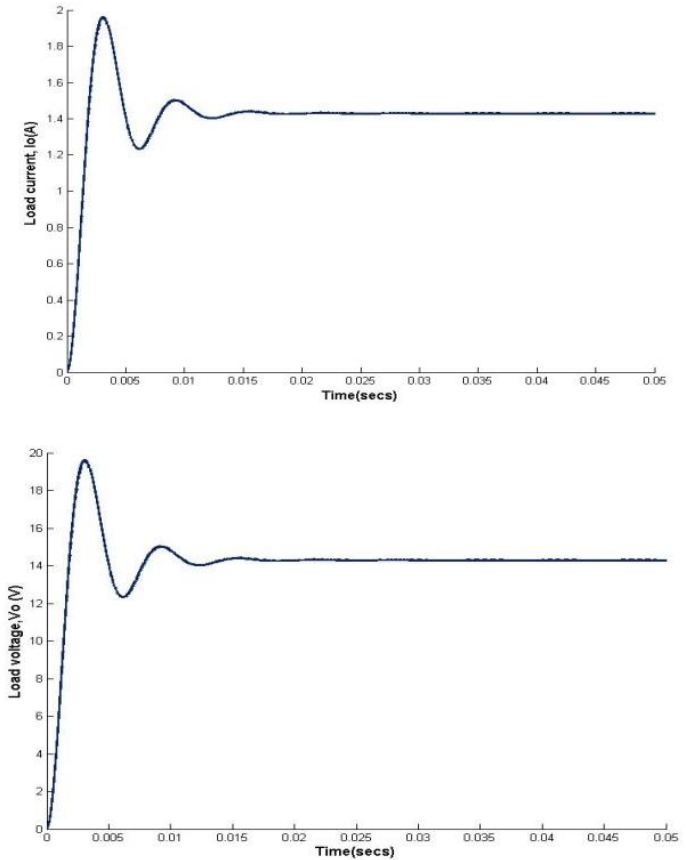

Fig. 7:Load current and loadvoltage waveform

\section{VI.CONCLUSION}

A Dual Input DC/DC converter is presented in this paper. The converter provides regulated load voltage. The proposed converter is simulated for Buck-Boost mode of operation using MATLAB/ Simulink.It can be seen that power can be delivered to load from two sources either simultaneously or individually.

\section{REFERENCES}

[1] Wei Jiang; Fahimi, B.; "Multiport Power Electronic InterfaceConcept, Modeling, and Design," Power Electronics, IEEE Transactions on , vol.26, no.7, pp.1890-1900, July 2011.

[2] Khaligh, A.; Zhihao Li; "Battery, Ultracapacitor, Fuel Cell, and Hybrid Energy Storage Systems for Electric, Hybrid Electric, Fuel Cell, and Plug-In Hybrid Electric Vehicles: State of the Art," Vehicular Technology, IEEE Transaction vol.59, no.6, pp.28062814, July2010.

[3] Valenciaga, F.; Puleston, P.F.; "Supervisor control for a stand-alone hybrid generation system using wind and photovoltaic energy," Energy Conversion, IEEE Transactions on , vol.20, no.2, pp. 398405, June 2005.

[4] Ozaki, Y.; Miyatake, M.; Iwaki, D.; "Power control of a stand-alone photovoltaic/ wind/ energy storage hybrid generation system with Maximum Power Point Tracker," Electrical Machines and Systems (ICEMS), 2010 International Conference on , vol., no., pp.607-611, 10-13 Oct. 2010.

[5] B. G. Dobbs and P. L. Chapman, "A multiple-input DC-DC converter," IEEE Power Electron Lett., vol. 1, no. 1, pp. 6-9, Mar. 2003.

[6] Khaligh, A.; Jian Cao; Young-Joo Lee; , "A Multiple-Input DC-DC Converter Topology," Power Electronics, IEEE Transactions on , vol.24, no.3, pp.862-868, March 2009.

[7] Yaow-Ming Chen; Yuan-Chuan Liu; Sheng-Hsien Lin; , "DoubleInput PWM DC/DC Converter for High-/Low-Voltage Sources," Industrial Electronics, IEEE Transactions on , vol.53, no.5, pp.1538-1545, Oct. 2006.

[8] Shailendra Jain and Lalit Kumar, "A novel dual input DC/DC converter topology," 2012 IEEE International Conference on Power Electronics, Drives and Energy systems, Dec 16-19, 2012.

[9] Kumar, L.; Jain, S.; "A novel multiple input DC-DC converter for electric vehicular applications," Transportation Electrification Conference and Expo (ITEC), 2012 IEEE , vol., no., pp.1-6, 18-20 June 2012.

[10] LinuLonappan and Dr. Sreedevi V.T.; " Analysis of double input DC-DC converters", International jounal of research in Electrical \& Electronics Engineering, vol 1, issue 2, oct-dec, 2013, pp.59-70.

[11] Shridhar Sholapur, K. R. Mohan, T. R. Narsimhegowda; " Boost Converter Topology for PV System with Perturb And Observe MPPT Algorithm", IOSR Journal of Electrical and Electronics Engineering, Volume 9, Issue 4 Ver. II (Jul - Aug. 2014), PP 5056. 